\title{
Effect of rearing temperature on larval growth and the development in different tilapia species
}

\author{
Nabil F. Abdel-Hakim ${ }^{1}$, Mostafa A. Mousa ${ }^{2}$, Mohsen S. Hussein ${ }^{1}$, Fatema A. El- \\ Nemaky ${ }^{3}$, El-Sayed I. Attia ${ }^{2}$ \\ 1- Department of Animal Production, Faculty of Agriculture, Al-Azhar University, \\ Cairo \\ 2- Fish Reproduction Laboratory, National Institute of Oceanography and Fisheries \\ 3- Central Laboratory of Aquaculture Research, Abbasa, Abo-Hammad, Sharkeyya
}

\section{ABSTRACT}

The present study deals with the effect of temperature on the development of different tilapia species (O. niloticus, red tilapia, $O$. aureus and hybrid tilapia $(O$. niloticus x $O$. aureus)) during larval rearing, and its subsequent effect on larval growth and survival. The development of the gills and the digestive tract was investigated histologically and histochemically in the developing control and temperature-exposed larvae of different tilapia species. The exposure of different tilapia species larvae to moderate level of temperature $\left(25-35^{\circ} \mathrm{C}\right)$ with a mean of $30^{\circ} \mathrm{C}$ greatly enhanced the development of gills and the digestive system of larvae as indicated by the quantitative and qualitative changes of the mucus composition from predominantly neutral to a mixture of neutral and acid mucosubstances, or acid mucosubstances occurred during the rearing period. This may be due to the direct effect of temperature on food intake and increasing of metabolism, enhanced the immunity of larvae or indirect effect of temperature on sex differentiation and producing high percentage of males which have rapid growth rate than females. Thus, rearing temperature directly or indirectly improved larval growth of different tilapia species, since a marked increase in both, length and weight of larvae occurred during the experimental period. In addition, temperature-exposed larvae also gave a significantly higher survival rate than that of control.

It could be concluded that the exposure of different tilapia species larvae to a rearing temperature of $30^{\circ} \mathrm{C}$ was effective for improvement of development and growth in a safe, simple and acceptable manner, as well as in a friendly approach to the environment.

Keywords: Fish larvae; different tilapia species; temperature; growth; digestive system.

\section{INTRODUCTION}

Early ontogeny in fish is impacted by nearly all environmental factors, including temperature, oxygen content, salinity, $\mathrm{pH}$, insolation, other biotic and anthropogenic factors (Jones, 2002; Kamler, 2002; 2008), and even precipitation and winds that blow along coasts (Bergenius et al. 2005). Among these factors, temperature is considered to be one of the more important, if not the most important, factors. Within a viable range, temperature plays a controlling role, beyond this range it is a lethal factor (Kamler 1992, 2002). The influence of temperature on the development, growth, and survival of embryos and larvae has been studied by Kujawa et al. (1997), Kamler et al. (1998), Hansen and Falk-Petersen (2001), Ojanguren and Braña (2003), KorwinKossakowski (2008). The influence of temperature on the metabolism has also been described by Jaworski and Kamler (2002), and Finn and Rønnestad (2003). 
In Egyptian tilapia hatcheries, the transition from endogenous to exogenous nutrition often results in high mortalities of Nile tilapia larvae, which might be attributed to nutritional and infection problems (Gisbert et al., 2004). The cause of mortalities may be physiological in nature given that starvation, due to the physical inability to feed after exhaustion of endogenous reserves. The period of mixed nutrition in rearing larvae of Nile tilapia, O. niloticus is considered as one of the most critical events during larval early life stages, since a several-day delay in feed availability influences posterior larval growth and survival.

The causes of mortalities in tilapia hatcheries are often unknown and complex, but microorganisms have been associated with epizootic mortalities (Ottesen and Olafsen, 2000). The specific immune system of fish is not fully matured until at least several weeks after hatching (Ellis, 1988; Chantanachookhin et al., 1991). Thus, until the appearance of lymphoid cells and production of immunoglobulins, fish larvae may have to rely largely on non-specific defense (Bly et al., 1986).

The epidermal mucus layer constitutes the primary biological interface between fish and the aqueous environment. A number of functions have been ascribed to the mucous layer, such as friction reduction (Pickering, 1974), protection against injury (Pickering and Richards, 1980), and ionoregulation. The mucus coat of fish also forms the primary barrier against infection (Pickering, 1974; Pickering and Macey, 1977; Ingram, 1980), and fish skin mucus may inhibit the growth of bacteria (Harrell et al., 1976; Fouz et al., 1990). In addition, the mucus plays an important role in various food processing activities (Murray et al., 1994; Vandenberg et al., 1994; Tibbetts, 1997; Gallagher et at, 2001).

Histological and histochemical description of the ontogeny of the digestive system may provide important information for the establishment of physiologically sound rearing methods to improve commercial larval rearing. Several studies have described the development of digestive tract organs in diverse fish species, including haddock (Hamlin et al., 2000), California halibut (Gisbert et al., 2004), Japanese eel larvae (Kurokawa et al., 2004), large yellow croaker (Mai et al., 2005), shi drum (Zaiss et al., 2006) and O. niloticus (Khalil et al., 2006; Hashem et al., 2011). However, there is no available information on the differentiation of the gastrointestinal tract of Nile tilapia during early life stages. As temperature increases, the developmental and growth rates accelerate (Jordaan and Kling 2003; Khalil et al., 2006; Kamiñski et al. 2006; Korwin-Kossakowski, 2008; Hashem et al., 2011). Also, temperature used as a detrimental factor in Nile tilapia sex differentiation in Egyptian hatcheries (Mousa, 2004).

Therefore, the objective of the present work was to describe the effect of water temperature on growth, survival and mucous cell activity during the development of gills and digestive system of different tilapia species (O. niloticus, red tilapia, $O$. aureus and hybrid tilapia (O. niloticus x $O$. aureus)), to provide a basis for future larval rearing protocol.

\section{MATERIALS AND METHODS}

\section{Study Site:}

The present study was carried out at both Shakshook-El-Fayyom Research Station and El-Matareyya Research Station-National Institute of Oceanography and Fisheries. The duration of the study was 5 months (150 days) starting from 1May to 30 September (2010-2012). 


\section{Treatments and spawning:}

Three groups of mouth-brooding tilapia, the Taiwanese red tilapia hybrid $(O$. niloticus $x$ O. mossambicus), Oreochromis aureus, Oreochromis niloticus and a hybridization between Oreochromis aureus males and Oreochromis niloticus females (O. aureus $x$ O. niloticus) were used in the present work. Before spawning, brood fish of each tilapia species were kept in two ponds; males and females were separated since January in two different ponds, they were fed daily with $40 \%$ protein diet to ensure a good quality and quantity of eggs. Medium-size tilapia brood fish (150-250 g) were used.

Semi-natural spawning was carried in spawning hapas at the first of May (temperature: $23-25^{\circ} \mathrm{C}$ ). Brood fish were stocked into 30 fine-mesh $1-\mathrm{m}^{2}$ spawning hapas at a rate of 2 males and 4 females per hapa. Breeding activity was monitored daily. Once breeding occurred, the other fish were removed and the brooding female left to incubate the progeny.

Immediately after hatching, the larvae with same ages were classified into three groups (three aquaria for each group). Since the sensitivity of fish to temperature is dependent on developmental stage (age), fry from a single brood were used in order to control the time elapsed after fertilization (and therefore, developmental stage). The density of larvae for each aquarium is about 500 larvae/aquarium i.e. 10 larvae/1. The first group of aquaria, was untreated (control), maintained at $25^{\circ} \mathrm{C}$. The second and third groups were exposed to either $30^{\circ} \mathrm{C}$ or $35^{\circ} \mathrm{C}$ temperatures. Water quality in the aquaria was maintained by partial water exchange (70\%) daily. Gentle aeration was conducted with pressurized air. Moreover all aquaria were kept under ambient photoperiod. The larvae received natural feed of fresh plankton obtained from fertilized pond with plankton net.

\section{Larvae sampling and processing:}

Both standard length (SL) and weight (W) of larvae at hatching; 14, 28 and 35 days old, were measured for each group. Twenty larvae were randomly sampled, anaesthetized, placed on paper towels for about 10 seconds to remove most of the adhering water, and individually both, measured and weighed. At the end of the experiment the surviving number for the different treatments were determined.

For histological and histochemical study, the larvae were anaesthetized in a solution $(40 \mathrm{mg} / \mathrm{l})$ of clove oil (Sigma) and fixed in toto in Bouin's fluid at room temperature for $48 \mathrm{~h}$. Then, the samples were transferred to $70 \%$ alcohol after fixation and dehydrated through series of graded ethanol, cleared in xylene, embedded in paraplast (M.P. $56-58^{\circ} \mathrm{C}$ ) and serial transverse and longitudinal sections, $5 \mu \mathrm{m}$ thick, were cut and mounted on glass slides. For each specimen, selected sections were stained with the following techniques:

1. Harris' alum hematoxylin, according to Conn (1953) and aqueous solution of eosin $(1 \%)$ was used as a counter stain.

2. Alcian blue (AB)/periodic acid-Schiff reagent (PAS) pH 1.0 (Bancroft and Cook, 1984). Positive reactions for mucous cell histochemistry at AB/PAS pH 1.0 were blue or blue greenish for acid mucins, red for neutral mucins and reddish purple for a combination of neutral and acid mucins.

Statistical analysis:

Results were analyzed with the SPSS (Statistical Package for Social Sciences) statistical package. Paired-samples " $t$ " test was applied to compare means. The level for accepted statistical significance was $\mathrm{P} \leq 0.05$. 


\section{RESULTS}

\section{The effect of temperature on growth and survival rate: i) Growth in length:}

The results in Table (1) showed that the rearing temperature improved larval growth of tilapia species; O. niloticus, Red tilapia $(O . s p)$, O. aureus and hybrid tilapia (O. niloticus x O. aureus). However, treatment with the high temperature $\left(35^{\circ} \mathrm{C}\right)$ gave significantly $(\mathrm{p} \leq 0.05)$ lower increase in length of larvae than low temperature $\left(30^{\circ} \mathrm{C}\right)$ as shown in Table (1).

Table 1: Body length (mean $\pm \mathrm{SD})$ of larvae for all treatments through experimental period (five weeks) in the different species; $O$ niloticus, red tilapia, $O$. aureus and hybrid tilapia (O. aureus male x O. niloticus female) at different water temperatures 25,30 and $35^{\circ} \mathrm{C}$.

\begin{tabular}{|c|c|c|c|c|c|c|c|c|c|c|c|c|}
\hline & \multicolumn{3}{|c|}{ O. niloticus } & \multicolumn{3}{|c|}{ Red tilapia } & \multicolumn{3}{|c|}{ O. aureus } & \multicolumn{3}{|c|}{ Hybrid tilapia } \\
\hline & $25^{\circ} \mathrm{C}$ & $30^{\circ} \mathrm{C}$ & $35^{\circ} \mathrm{C}$ & $25^{\circ} \mathrm{C}$ & $30^{\circ} \mathrm{C}$ & $35^{\circ} \mathrm{C}$ & $25^{\circ} \mathrm{C}$ & $30^{\circ} \mathrm{C}$ & $35^{\circ} \mathrm{C}$ & $25^{\circ} \mathrm{C}$ & $30^{\circ} \mathrm{C}$ & $35^{\circ} \mathrm{C}$ \\
\hline Zero time & $\begin{array}{c}1.2 \\
\pm \\
0.06\end{array}$ & $\begin{array}{c}1.2 \\
\pm \\
0.06\end{array}$ & $\begin{array}{c}1.2 \\
\pm \\
0.06\end{array}$ & $\begin{array}{c}1.2 \\
\pm \\
0.06\end{array}$ & $\begin{array}{c}1.2 \\
\pm \\
0.06\end{array}$ & $\begin{array}{c}1.2 \\
\pm \\
0.06\end{array}$ & $\begin{array}{c}1.2 \\
\pm \\
0.06\end{array}$ & $\begin{array}{c}1.2 \\
\pm \\
0.06\end{array}$ & $\begin{array}{c}1.2 \\
\pm \\
0.06\end{array}$ & $\begin{array}{c}1.2 \\
\pm \\
0.06\end{array}$ & $\begin{array}{c}1.2 \\
\pm \\
0.06\end{array}$ & $\begin{array}{c}1.2 \\
\pm \\
0.06\end{array}$ \\
\hline $\begin{array}{c}\text { After four } \\
\text { weeks }\end{array}$ & $\begin{array}{c}2.4 \\
\pm \\
0.12\end{array}$ & $\begin{array}{c}3.4^{\mathrm{a}} \\
\pm \\
0.17\end{array}$ & $\begin{array}{c}3.2^{\mathrm{a}} \\
\pm \\
0.16\end{array}$ & $\begin{array}{c}2.5 \\
\pm \\
0.13\end{array}$ & $\begin{array}{c}3.3^{\mathrm{a}} \\
\pm \\
0.165\end{array}$ & $\begin{array}{c}3.1^{\mathrm{a}} \\
\pm \\
0.16\end{array}$ & $\begin{array}{c}2.5 \\
\pm \\
0.13\end{array}$ & $\begin{array}{c}3.4^{\mathrm{a}} \\
\pm \\
0.17\end{array}$ & $\begin{array}{c}3.0^{\mathrm{a}} \\
\pm \\
0.15\end{array}$ & $\begin{array}{c}2.4 \\
\pm \\
0.12\end{array}$ & $\begin{array}{c}3.4^{\mathrm{a}} \\
\pm \\
0.17\end{array}$ & $\begin{array}{c}3.1^{\mathrm{a}} \\
\pm \\
0.16\end{array}$ \\
\hline $\begin{array}{c}\text { After five } \\
\text { weeks }\end{array}$ & $\begin{array}{c}3.2 \\
\pm \\
0.16\end{array}$ & $\begin{array}{c}4.4^{\mathrm{a}} \\
\pm \\
0.22\end{array}$ & $\begin{array}{c}4.0^{\mathrm{a}} \\
\pm \\
0.2\end{array}$ & $\begin{array}{c}3.3 \\
\pm \\
0.165\end{array}$ & $\begin{array}{c}4.5^{\mathrm{a}} \\
\pm \\
0.23\end{array}$ & $\begin{array}{c}4.2^{\mathrm{a}} \\
\pm \\
0.21\end{array}$ & $\begin{array}{c}3.4 \\
\pm \\
0.17\end{array}$ & $\begin{array}{c}4.5^{\mathrm{a}} \\
\pm \\
0.23\end{array}$ & $\begin{array}{c}4.1^{\mathrm{a}} \\
\pm \\
0.21\end{array}$ & $\begin{array}{c}3.2 \\
\pm \\
0.16\end{array}$ & $\begin{array}{c}4.4^{\mathrm{a}} \\
\pm \\
0.22\end{array}$ & $\begin{array}{c}4.1^{\mathrm{a}} \\
\pm \\
0.21\end{array}$ \\
\hline
\end{tabular}

a: Significant differences when compared to $25^{\circ} \mathrm{C}(\mathrm{P}<0.05)$.

\section{ii) Growth in weight:}

The larvae of tilapia species; O. niloticus, Red tilapia (O. sp), O. aureus and hybrid tilapia (O. niloticus x O. aureus) reared at high levels of temperature, i.e. 30 $35^{\circ} \mathrm{C}$, exhibited significantly $(\mathrm{p} \leq 0.05)$ greater average body weight than those of control $\left(25^{\circ} \mathrm{C}\right)$ as represented in Table (2). However, the exposure to high temperature $\left(35^{\circ} \mathrm{C}\right)$ gave significantly $(\mathrm{p} \leq 0.05)$ lower values of larval body weight than low temperature $\left(30^{\circ} \mathrm{C}\right)$ as represented in Table (2).

Table 2: Body weight (mean $\pm \mathrm{SD}$ ) of larvae for all treatments through experimental period (five weeks) in the different species; $O$ niloticus, red tilapia, O. aureus and hybrid tilapia (O. aureus male x $O$. niloticus female) at different water temperaturess 25,30 and $35^{\circ} \mathrm{C}$.

\begin{tabular}{|c|c|c|c|c|c|c|c|c|c|c|c|c|}
\hline & \multicolumn{3}{|c|}{ O. niloticus } & \multicolumn{3}{c|}{ Red tilapia } & \multicolumn{3}{c|}{ O. aureus } & \multicolumn{3}{c|}{ Hybrid tilapia } \\
\cline { 2 - 13 } & $25^{\circ} \mathrm{C}$ & $30^{\circ} \mathrm{C}$ & $35^{\circ} \mathrm{C}$ & $25^{\circ} \mathrm{C}$ & $30^{\circ} \mathrm{C}$ & $35^{\circ} \mathrm{C}$ & $25^{\circ} \mathrm{C}$ & $30^{\circ} \mathrm{C}$ & $35^{\circ} \mathrm{C}$ & $25^{\circ} \mathrm{C}$ & $30^{\circ} \mathrm{C}$ & $35^{\circ} \mathrm{C}$ \\
\hline Zero time & 0.014 & 0.014 & 0.014 & 0.015 & 0.015 & 0.015 & 0.014 & 0.014 & 0.014 & 0.014 & 0.014 & 0.014 \\
& \pm & \pm & \pm & \pm & \pm & \pm & \pm & \pm & \pm & \pm & \pm \\
\pm & \pm & \pm & \pm & \pm \\
& 0.007 & 0.007 & 0.007 & 0.007 & 0.007 & 0.007 & 0.007 & 0.007 & 0.007 & 0.007 & 0.007 & 0.007 \\
\hline After four & 0.261 & $0.45^{\mathrm{a}}$ & $0.41^{\mathrm{a}}$ & 0.27 & $0.44^{\mathrm{a}}$ & $0.40^{\mathrm{a}}$ & 0.26 & $0.49^{\mathrm{a}}$ & $0.40^{\mathrm{a}}$ & 0.26 & $0.55^{\mathrm{a}}$ & $0.41^{\mathrm{a}}$ \\
weeks & \pm & \pm & \pm & \pm & \pm & \pm & \pm & \pm & \pm & \pm & \pm & \pm \\
& 0.013 & 0.023 & 0.021 & 0.014 & 0.022 & 0.02 & 0.013 & 0.025 & 0.02 & 0.013 & 0.028 & 0.021 \\
\hline After five & 0.63 & $0.9^{\mathrm{a}}$ & $0.7^{\mathrm{a}}$ & 0.65 & $0.98^{\mathrm{a}}$ & $0.84^{\mathrm{a}}$ & 0.74 & $1.0^{\mathrm{a}}$ & $0.91^{\mathrm{a}}$ & 0.62 & $0.97^{\mathrm{a}}$ & $0.77^{\mathrm{a}}$ \\
weeks & \pm & \pm & \pm & \pm & \pm & \pm & \pm & \pm & \pm & \pm & \pm & \pm \\
& 0.032 & 0.045 & 0.035 & 0.033 & 0.049 & 0.042 & 0.037 & 0.05 & 0.046 & 0.031 & 0.049 & 0.039 \\
\hline
\end{tabular}

a: Significant differences when compared to $25^{\circ} \mathrm{C}(\mathrm{P}<0.05)$.

\section{iii) Survival rate:}

The data represented in Table (3) showed that the exposure of tilapia species; $O$. niloticus, Red tilapia (O. sp), O. aureus and hybrid tilapia (O. niloticus x O. aureus) larvae to high levels of temperature $\left(30-35^{\circ} \mathrm{C}\right)$ ) improved larval rearing, since low mortalities occurred over the rearing period of 35 days. The larvae exposed to high temperature exhibited significantly $(\mathrm{p} \leq 0.05)$ higher survival rate than control. 
However, the exposure to high temperature $\left(35^{\circ} \mathrm{C}\right)$ resulted in a significantly lower survival rate than low temperature $\left(30^{\circ} \mathrm{C}\right)$.

Table (3): Survival rate (\%), (mean \pm SD) of larvae for all treatments through experimental period (5 weeks) in the different species; $O$ niloticus, red tilapia, $O$. aureus and hybrid tilapia $(O$. aureus male x $O$. niloticus female) at different water temperature 25,30 and $35^{\circ} \mathrm{C}$.

\begin{tabular}{|l|l|l|l|l|}
\hline \multirow{2}{*}{$\begin{array}{l}\text { Temperature } \\
\text { degree }\end{array}$} & \multicolumn{4}{|c|}{ Tilapia species } \\
\cline { 2 - 5 } & O. niloticus & Red tilapia & O. aureus & Hybrid tilapia \\
\hline $\mathbf{2 5}^{\circ} \mathbf{C}$ & $42 \pm 2.1$ & $41 \pm 2.05$ & $41 \pm 2.05$ & $40 \pm 2.00$ \\
\hline $\mathbf{3 0}^{\circ} \mathbf{C}$ & $90 \pm 4.5^{\text {a }}$ & $90 \pm 4.50^{\text {a }}$ & $91 \pm 4.55^{\text {a }}$ & $91 \pm 4.55^{\text {a }}$ \\
\hline $\mathbf{3 5}^{\circ} \mathbf{C}$ & $80 \pm 4.0^{\text {a }}$ & $81 \pm 4.05^{\text {a }}$ & $80 \pm 4.00^{\text {a }}$ & $79 \pm 3.95^{\text {a }}$ \\
\hline
\end{tabular}

a: Significant differences when compared to $25^{\circ} \mathrm{C}(\mathrm{P}<0.05)$.

\section{The effect of temperature on the histology and histochemistry of the gills and} the digestive system:

i) Gills:

The exposure of tilapia species larvae to high degrees of temperatures; $30^{\circ} \mathrm{C}$ enhanced the production of mucin in the developing gills of larvae as indicated by the increased numbers and strong staining of mucous cells at 35 days of age in comparison with the control group; $25^{\circ} \mathrm{C}$ (Fig. 1).

ii) Digestive system:

The larvae of different tilapia species were reared in different regime of temperatures for a period of 35 days. We followed up the changes occurred in digestive system; buccopharynx and intestine after the temperature-exposure period (Figs. 2 and 3).

\section{Buccopharynx:}

Figure (2) showed numerous mucous cells in the buccopharyngeal epithelium of larvae reared at high temperature $\left(30^{\circ} \mathrm{C}\right)$ compared to those reared at low temperature $\left(25^{\circ} \mathrm{C}\right)$.

\section{Intestine:}

In the intestine of the temperature-exposed larvae $\left(30^{\circ} \mathrm{C}\right)$ after $35 \mathrm{dph}$, the mucosal folds were very long with round tips. Mucus cells were highly abundant and contain intense NMPS (Fig. 3).

\section{DISCUSSION}

The first few weeks of development become a critical period for fish larvae, particularly when the yolk-sac is reabsorbed and exogenous feeding starts. The present study examined the effects of rearing temperature on the development of the gills and the digestive system during larval development of tilapia species; $O$. niloticus, Red tilapia (O. $s p$ ), O. aureus and hybrid tilapia (O. niloticus x O. aureus), and its subsequent effect on larval growth and survival. The exposure to high levels of temperature $\left(30-35^{\circ} \mathrm{C}\right)$ accelerated larval growth, since a higher increase in both, length and weight of larvae occurred during the experimental period. Larvae exposed to higher temperature gave also a significantly $(\mathrm{p} \leq 0.05)$ higher survival rate than that of control. Similar reports showed that, water temperatures within the range of 26$28^{\circ} \mathrm{C}$ during the early development of common carp ensures optimum results during further rearing; while for grass carp the optimal temperature for early development is $32^{\circ} \mathrm{C}$ (Korwin-Kossakowski, 2008). The primary goal of producing stocking material is to obtain larger individuals in a shorter period of time (Kamler et al. 1998). Since high temperatures in the viable range shorten development time and accelerate 
growth, thus limiting losses caused by periods of starvation (Kamler et al. 1998, Jones 2002), the usefulness of applying high temperatures is obvious.

The histological studies of the gills and the alimentary canal across species of fish are becoming more valuable as the interest in fish culture expands and more information is required with regard to acclimatization, feeding and nutrition (Murrey et al., 1994). The exposure of different tilapia species larvae to moderate level of temperature $\left(25-35^{\circ} \mathrm{C}\right)$ with a mean of $30^{\circ} \mathrm{C}$ greatly enhanced the development of gills and the digestive system of larvae as indicated by the quantitative and qualitative changes of the mucus composition from predominantly neutral to a mixture of neutral and acid mucosubstances, or acid mucosubstances occurred during the rearing period. In the present study, taste buds and mucus cells in the bucco-pharyngeal cavity of the temperature-exposed larvae $\left(30^{\circ} \mathrm{C}\right)$ are abundant. The abundance of taste buds in the bucco-pharyngeal cavity of the fish is rather to be correlated with the way in which the fish scores its food rather than with the nature of its diet. On the other hand, the concentration of mucus cells in bucco-pharynx shows that, this part is primarily concerned with mucus production, to facilitate swallowing of food and to entrap small food particles (Shehata, 1999).

In the current study, the presence of functional bucco-pharyngeal mucous cells secreting mucins, which are known to play an important role in protecting the mucosa against bacterial attack and, physical and chemical damage, added to the fact that, no histopathological alterations, nor bacteria were detected in the gut mucosa and lumen, respectively (Allen, 1989). This seemed to indicate that such high mortality rates during larval rearing of the fish, particularly throughout the stages of first feeding when larvae undergo intense organogenesis, was probably linked to nutritional deficits and imbalances rather than to infection problems. Teleostean mucous cells are known to contain carbohydrates without characterizing their specific nature. An abundance of mucous cells indicates that bucco- pharyngeal mucosubstances have some role in the digestive process and different mucosubstances found in different regions of the gut are correlated with assorted digestive functions (Murrey et al., 1994). In the present study, mucus cells are abundant in the bucco- pharyngeal and contain neutral MPS. Mucus secreted in the digestive tract is the first protective barrier against mechanical, physical and chemical factors as well as against infections (Morrison and Wright 1999; Yashpal et al. 2007). Numerous PAS positive mucous cells appeared along the digestive tract, suggest that, these cells play an important role in pregastric digestion in larvae (Baglole et al., 1997).

In the present study, the number of mucous cells in the gut of the temperatureexposed larvae $\left(30^{\circ} \mathrm{C}\right)$ increased with larval development. The components of mucous cells in the bucco- pharyngeal were mainly sulphated mucosubstances, to protect the mucosa against chemicals, parasites, hypertonic media and acidity, as well as to provide lubrication for ingested food particles (Shephard, 1994 and Zaiss et al., 2006).

In the present study, the intestinal mucosal folds in the temperature-exposed larvae $\left(30^{\circ} \mathrm{C}\right)$ are very long compared with control. The submucosa consists of loose areolar connective tissue, richly supplied with lymphocytes granulocytes and blood vessels. The circular layer of muscle fibers is relatively thicker than the longitudinal one. Murrey et al. (1994) concluded that, the thick layer of connective tissue between the mucosa and the muscle cells, as well as the deep longitudinal folds found in $T$. brasiliensis will probably help to reinforce and maintain the integrity of the walls of the organ when a great amount of food is ingested at one time or when preys are swallowed as a whole. In the temperature-exposed larvae $\left(30^{\circ} \mathrm{C}\right)$, mucus cells were many in the intestine and increased in number with larval development. The mucus 
cells contain neutral muccosubstances. The presence of neutral mucins in the digestive tract has been related to the absorption of easily digested substances, such as disaccharides and short chain fatty acids (Osman and Caceci, 1991). In most teleosts, the anterior intestine is involved in the absorption of lipids and it is characterized by lipid inclusions in the epithelial cells of the mucosa, which are considered as a temporary storage site (Rombout et al., 1984; Kjørsvik et al., 1991). In the present study, no lipid inclusions were observed in the anterior segment of the intestinal mucosa of the fish larvae, although lipid vacuoles increased in the liver throughout development. These results are similar to those already reported in P. californicus (Gisbert et al., 2004) and Hipoglossus hipoglossus (Luizi et al., 1999). These authors suggested that the lack of such lipid vacuoles in the intestine of Artemia sp.-fed larvae could be interpreted as a sign of reduced intestinal lipid digestion due to the rapid passage of Artemia sp. through the alimentary canal of larvae (Luizi et al., 1999); whereas, Gisbert et al. (2004) hypothesized that the lipid content of feed did not exceed the fatty acid absorption and exporting capacities of enterocytes, resulting in no accumulation of lipids in the intestinal mucosa.

In conclusion, the ontogeny of the digestive system in the larvae of tilapia species is good pattern in the temperature-exposed larvae $\left(30^{\circ} \mathrm{C}\right)$. However, species specific differences in the appearance of functional mucous cells were noticed. Future work must be focused on the ontogeny of enzymatic secretions to provide precise information about the functionality of the digestive tract and to evaluate the effect of different feeding and weaning strategies on digestive tract maturation.

\section{REFERENCES}

Allen, A. (1989). Gastrointestinal mucus. In Handbook of Physiology (Schultz, S. G., Forte, J. G. \& Raumer, B. B., eds), pp. 359-382. Bethesda, MD: American Physiolo. Soci.

Baglole, C.J.; Murray, H.M.; Goff, G.P. and Wright, G.M. (1997). Ontogeny of the digestive tract during larval development of the Yellow tail flounder: a light microscopy and mucous histochemical study. J. Fish Biol., 51:120-134.

Bancroft, J.D. and Cook, H.C. (1984). Manual of histological Techniques. New York: Churchill Livingstone.

Bergenius, M. A. J.; McCormick, M. I.; Meekan, M. G. and Robertson, D. R. (2005). Environmental influences on larval duration, growth and magnitude of settlement of a coral reef fish. Mar. Biol., 147: 291-300.

Bly, J. E.; Grimm, A. S. and Morris, I. G. (1986). Transfer of passive immunity from mother to young in a teleost fish: haemagglutinating activity in the serum and eggs of plaice, Pleuronectes platessa (L). Comp. Biochem. Physiol. 84 (A): 309-313.

Chantanachookhin, C.; Seikai, T. and Tanaka, M. (1991). Comparative study of the ontogeny of the lymphoid organs in three species of marine fish. Aquacult., 99: 143-155.

Conn, H. J. (1953). "Biological Stains" (Williams and Wilkins Company, Baltimore).

Ellis, A.E. (1988). Ontogeny of the immune system in teleost fish. In: Ellis, A.E. (Ed.), Fish Vaccination. Academic Press, London, pp. 20-31.

Finn, R. N. and Rønnestad, I. (2003). The effect of acute changes in temperature and light on the aerobic metabolism of embryos and yolk-sac larvae of turbot (Scophthalmus maximus). Can. J. Fish. Aquat. Sci., 60: 1324-1331. 
Fouz, B.; Devesa, S.; Graviningen, K.; Barja, J.L. and Toranzo, A. E. (1990). Antibacterial action of the mucus of turbot. Bull. Eur. Assoc. Fish Pathol. 10: 56-59.

Gallagher, M.L.; Luczkovich, J.J. and Stellwag, E.J. (2001). Characterization of the ultrastructure of the gastrointestinal tract mucosa, stomach contents and liver enzyme activity of the pinfish during development. J. Fish Biol., 58(6): 17041713.

Gisbert, E.; Piedrahita, R.H. and Conklin, D.E. (2004). Ontogenetic development of the digestive system in California halibut, Paralichthys californicus with notes on feeding practices. Aquacult., 232: 455-470.

Hamlin, H.; Hunt von Herbing, I. and Kling, L. (2000). Histological and morphological evaluations of the digestive tract and associated organs of haddock throughout post-hatching ontogeny. J. Fish Biol., 57: 716-732.

Hansen, T. K. and Falk-Petersen, I. B. (2001). The influence of rearing temperature on early development and growth of spotted wolffish Anarhichas minor (Olafsen). Aquacult. Res., 32: 369-378.

Harrell, L. W.; Etlinger, H. M. and Hodgins, H. O. (1976). Humoral factors important in resistance of salmonid fish to bacterial disease: II. Anti-Vibrio anguillarum activity in mucus and observations on complement. Aquacult., 7: 363-370.

Hashem, A. M.; El-Gohary, N. M. and Khalil, N. A. (2011). Effect of rearing temperature on larval growth and the digestive system development in Nile tilapia, Oreochromis niloticus. J. Egypt. Ger. Soc. Zool., 64(C): 49-76.

Jaworski, A. and Kamler, E. (2002). Development of a bioenergetics model for fish embryos and larvae during the yolk feeding period. J. Fish Biol., 60:785-809.

Ingram, G.A. (1980): Substances involved in the natural resistance of fish to infection, a review. J. Fish Biol., 16: 23-60

Jones, C. M. (2002). Age and growth. In: Fishery Science. The unique contributions of early life stages (Eds) L.A. Fuiman and R. G. Werner, Blackwell Publishing, 33-63.

Jordaan, A. and Kling, L. J. (2003). Determining the optimal temperature range for Atlantic cod (Gadus morhua) during early life. In: The Big Fish Bang (Eds) H.I., Browman and A.B., Skiftesvik. Proceedings of the $26^{\text {th }}$ Annual Larval Fish Conference. Institute of Marine Research, Bergen, Norway: 45-62.

Kamiñski, R.; Kamler, E.; Korwin-Kossakowski, M.; Myszkowski, L. and Wolnicki, J. (2006). Effects of different incubation temperatures on the yolk-feeding stage of Eupallasella percnurus (Pallas). J. Fish Biol., 68:1077-1090.

Kamler, E. (1992). Early life history of fish: an energetics approach. Chapman \& Hall, London, 267 p.

Kamler, E. (2002). Ontogeny of yolk-feeding fish: an ecological perspective. Reviews in Fish Biolo. \& Fish., 12: 79-103

Kamler, E. (2008). Resource allocation in yolk-feeding fish. Rev. Fish Biol. Fish., 18:143-200.

Kamler, E.; Keckeis, H. and Bauer-Nemeschkal, E. (1998). Temperature-induced changes of survival, development and yolk partitioning in Chondrostoma nasus. J. Fish Biol., 53: 658-682.

Khalil, N. A.; El-Gamal, A. S. and Mousa, M. A. (2006). The effect of exogenous treatment with hormones and temperature on growth and the activity of CRFand mucus-secreting cells during the development of Oeochromis niloticus larvae. J. Egypt. Soc. Environ. Develop., 7 (1): 33-56. 
Kjørsvik, E.; Van der Meeren, T.; Kryvi, H.; Arnfinnson, J. and Kvenseth, P.G. (1991). Early development of the digestive tract of cod larvae, Gadus morhua during start-feeding and starvation. J. Fish Biolo., 38:1-15.

Korwin-Kossakowski, M. (2008). The influence of temperature during the embryonic period on larval growth and development in carp, Cyprinus carpio L., and grass carp, Ctenopharyngodon idella (Val.): Theoretical and practical aspects. Arch. Pol. Fish., 16: 231-314.

Kujawa, R.; Mamcarz, A. and Kucharczyk, D. (1997). Effect of temperature on embryonic development of asp (Aspius aspius L.). Pol. Arch. Hydrobiol., 44: 139-143.

Kurokawa, T.; Iinuma, N.; Unuma, T.; Tanaka, H.; Kagawa, H.; Ohta, H. and Suzuki, T. (2004). Development of endocrine system regulating exocrine pancreas and estimation of feeding and digestive ability in Japanese eel larvae. Aquacult., 234: 513-525.

Luizi, F. S.; Gara, B.; Shields, R. J. and Bromage, N. R. (1999). Further description of the development of the digestive organs in Atlantic halibut, Hippoglossus hippoglossus larvae, with notes on differential absorption of copepod and Artemia prey. Aquacult., 176: 101-116.

Mai, K.; Yu, H.; Ma, H.; Duan, Q.; Gisbert, E.; Zambonino Infante, J.L. and Cahu, C. (2005). A histological study on the development of the digestive system of Pseudosciaena crocea larvae and juveniles. J. Fish Biolo., 67: 1094-1106.

Morrison, C.M. and Wright, J. R. (1999). A study of the histology of the digestive tract of the Nile tilapia. J Fish Biol., 54:597-606.

Mousa, M.A. (2004). Aromatase activity during normal and induced sex differentiation of the Nile tilapia Oreochromis niloticus. J. Union Arab Biol. Cairo, 22 (A) Zool.: 1-20.

Murrey, H.M.; Wright, G.M. and Goff, G.P. (1994). A study of the posterior esophagus in the winter flounder, Pleuronectes americanus, and the yellowtail flounder, Pleuronectes ferruginea: a morphological evidence of pregastric digestion? Can. J. Zool., 72: 1191-1198.

Ojanguren, A.F. and Braña, F. (2003). Thermal dependence of embryonic growth and development in brown trout. J. Fish Biol., 62: 580-590.

Osman, A.H.K. and Caceci, T. (1991). Histology of the stomach of Tilapia nilotica_Linnaeus, 1758.from the river Nile. J. Fish Biol., 38: 221-223.

Ottesen, O.H. and Olafsen, J.A. (2000). Effects on survival and mucous cell proliferation of Atlantic halibut, Hippoglossus hippoglossus L., larvae following microflora manipulation. Aquacult., 187: 225-238.

Pickering, A.D. (1974). The distribution of mucous cells in the epidermis of the brown trout Salmo trutta (L.) and the char Salvelinus alpinus (L.). J. Fish Biol., 6: 111-118.

Pickering, A. D. and Macey, D. J. (1977). Structure, histochemistry and the effect of handling on the mucous cells in the epidermis of the char Salvelinus alpinus (L.). J. Fish Biol., 10: 505-512

Pickering, A. D. and Richards, R. H. (1980). Factors influencing the structure, function and biota of the salmonid epidermis. Proc. R. Soc. Edinburg, 79 (B): 93-104.

Rombout, J. H. W. M.; Stroband, H. W. J. and Taverne-Thiele, J. J. (1984). Proliferation and differentiation of intestinal epithelial cells during development of Barbus conchius (Teleostei, Cyprinidae). Cell Tissue Res., 236: 207-216. 
Shehata, S. M. A. (1999). Studies on the anatomy and histochemistry of the digestive tract in the fingerling stages of the grass carp, Ctenopharyngdon idella (Valenciennes), in relation to food and feeding habits. Egypt. J. Aqua. Boil. \& Fish., 13 (1): 113-145.

Shephard, K. L. (1994). Functions for fish mucus. Reviews in Fish Biolo. \& Fish., 4: 401-429.

Vandenberg, C.; Vandenboogaart, J.G.M.; Sibbing, F.A. and Osse, J.W.M. (1994): Implications of gill arch movements for filter feeding: An X-Ray cinematographical study of filter-feeding white bream (Blicca bjoerkna) and common bream (Abramis brama). J. Exp. Biol., 191: 257-282.

Tibbetts, I.R. (1997). The distribution and function of mucous cells and their secretions in the alimentary tract of Arrhamphus sclerolepis krefftii. J. Fish Biol., 50: 809-820.

Yashpal M.; Kumari U.; Mittal S. and Mittal A.K. (2007). Histochemical characterization of glycoproteins in the buccal epithelium of the catfish, Rita rita. Acta Histochem, 109: 285-303.

Zaiss, M.; Papadakis, I.; Divanach, P.; Maingot, E. and Mylonas, C.C. (2006). Ontogeny of the digestive tract in shi drum, Umbrina cirrrosa reared using the mesocosm larval rearing system. Aquacult., 260: 357-368. 


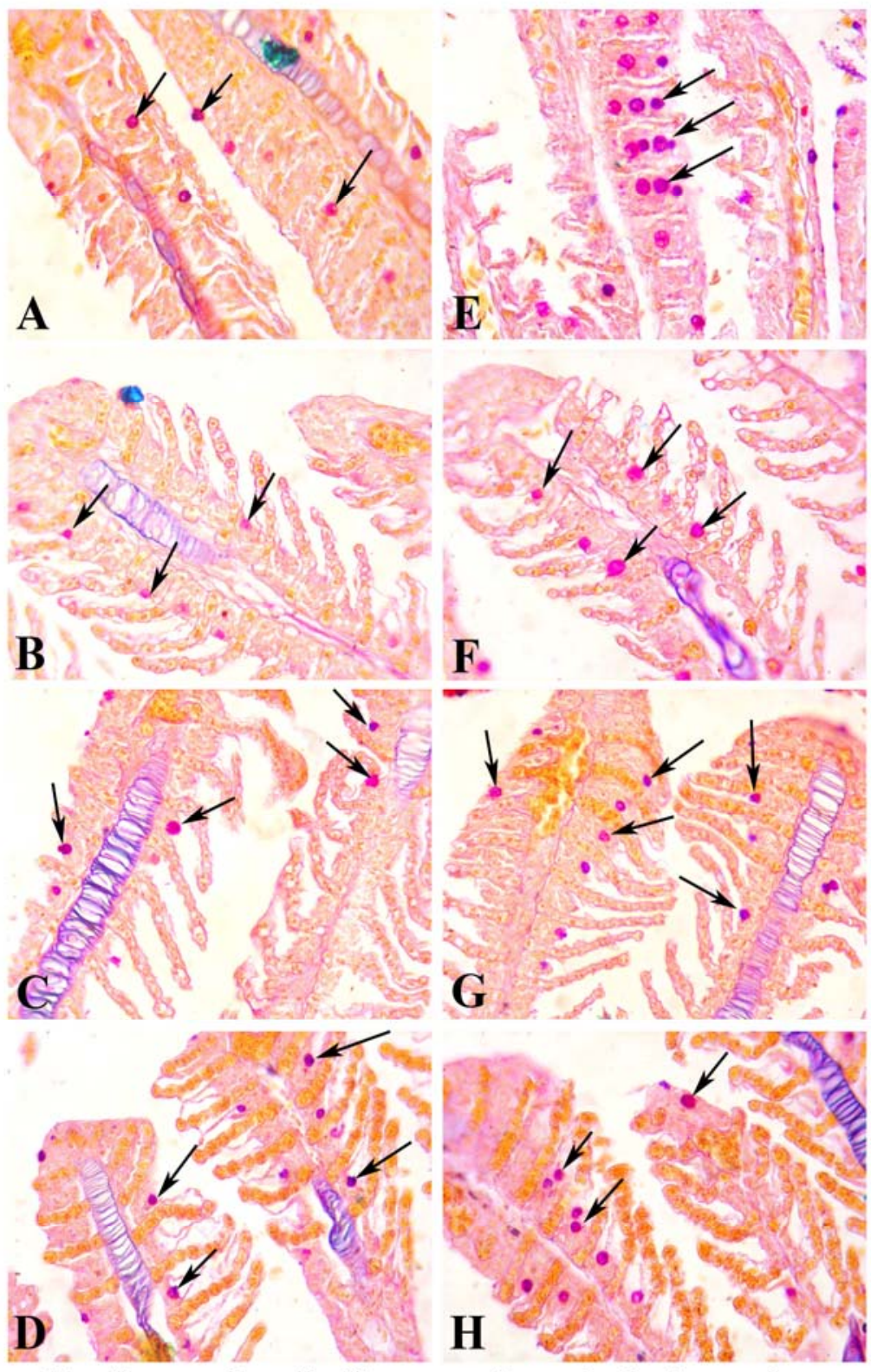

Fig. (1): Changes in gill filaments of tested tilapia species as affected with raring temperatures showing enhanced production of mucin due to the increase in temperature. Stained with AB-PAS - OG; $\mathrm{X} 400$
A) Control O.niloticus $\left(25^{\circ} \mathrm{C}\right)$
E) O.niloticus $\left(30^{\circ} \mathrm{C}\right)$
B) Control Red tilapia $\left(25^{\circ} \mathrm{C}\right)$
F) Red tilapia $\left(30^{\circ} \mathrm{C}\right)$
C) Control O.aureus $\left(25^{\circ} \mathrm{C}\right)$
$\mathrm{G})$ O.aureus $\left(30^{\circ} \mathrm{C}\right)$
D) Control hybrid tilapia O.aureus x O.niloticus $\left.\left(25^{\circ} \mathrm{C}\right) \mathrm{H}\right)$ Hybrid tilapia $\left(30^{\circ} \mathrm{C}\right)$ 

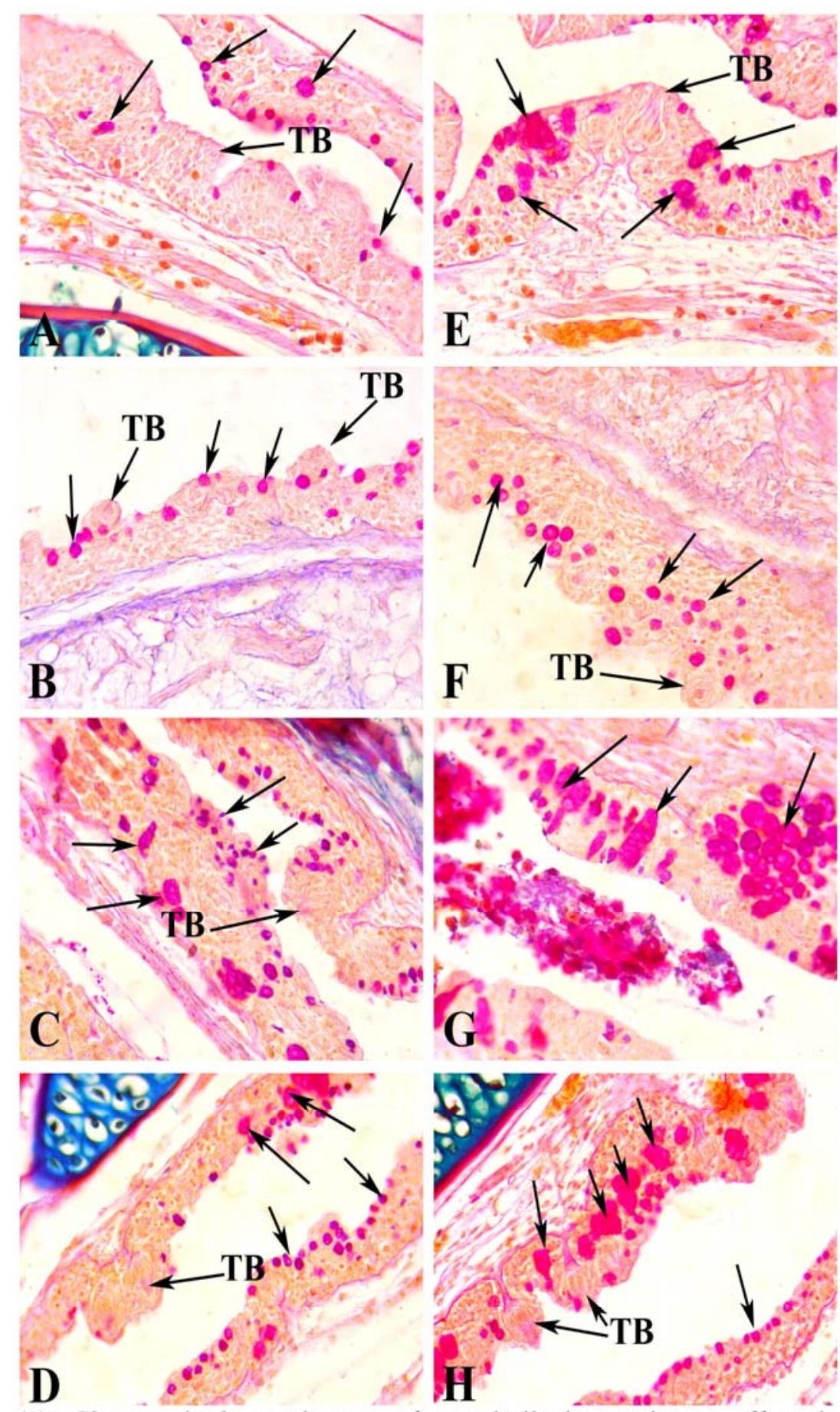

Fig. (2): Changes in buccopharynx of tested tilapia species as affected with rearing temperatures. Fig (2) shows increased the density of mucus cells in fish exposed to $\left(30^{\circ} \mathrm{C}\right)$ compared to $\left(25^{\circ} \mathrm{C}\right)$. Stained with AB-PAS - OG; X 400
A) Control O.niloticus $\left(25^{\circ} \mathrm{C}\right)$
E) O.niloticus $\left(30^{\circ} \mathrm{C}\right)$
B) Control Red tilapia $\left(25^{\circ} \mathrm{C}\right)$
F) Red tilapia $\left(30^{\circ} \mathrm{C}\right)$
C) Control O.aureus $\left(25^{\circ} \mathrm{C}\right)$
G) O.aureus $\left(30^{\circ} \mathrm{C}\right)$
D) Control hybrid tilapia O.aureus $\mathrm{x}$ O.niloticus $\left.\left(25^{\circ} \mathrm{C}\right) \mathrm{H}\right)$ Hybrid tilapia $\left(30^{\circ} \mathrm{C}\right)$ 


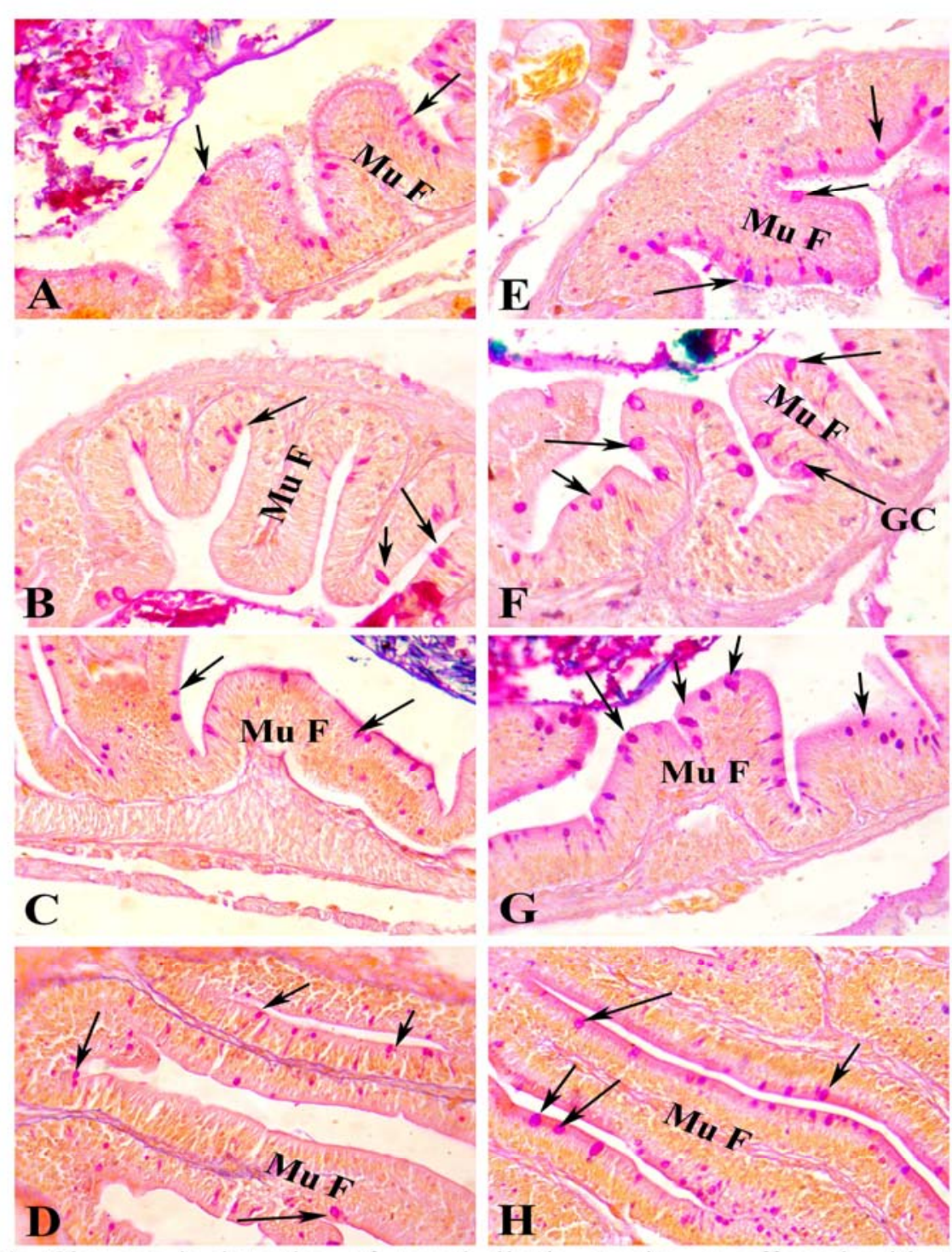

Fig.(3): Changes in intestine of tested tilapia species as affected with raring temperatures showing that the mucosal folds in the temperature exposed larvae are very long compared to the ontrol and rich supplied with blood vessels, Stained with AB-PAS-OG; $\quad$ X 400
A) Control O.niloticus $\left(25^{\circ} \mathrm{C}\right)$
B) Control Red tilapia $\left(25^{\circ} \mathrm{C}\right)$
E) O.niloticus $\left(30^{\circ} \mathrm{C}\right)$
C) Control O.aureus $\left(25^{\circ} \mathrm{C}\right)$
F) Red tilapia $\left(30^{\circ} \mathrm{C}\right)$
D) Control hybrid tilapia O.aureus x O.niloticus $\left(25^{\circ} \mathrm{C}\right.$
G) O.aureus $\left(30^{\circ} \mathrm{C}\right)$
H) Hybrid tilapia $\left(30^{\circ} \mathrm{C}\right)$ 


\section{ARABIC SUMMRY}

تأثير درجة حرارة التحضين على نمو وتطور اليرقات فى أنواع مختلفة من أسماك البلطى

نبيل فهمى عبدالحكيم' - مصطفى عبد الوهاب موسي" ــ محسن صالح حسين' ـ فاطمة أمين النمكى"

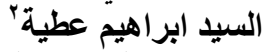

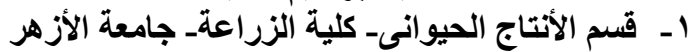

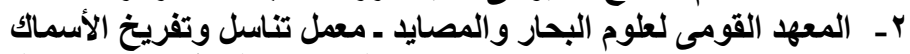

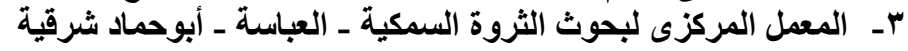

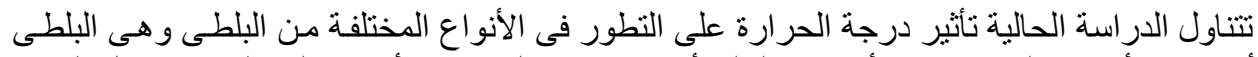

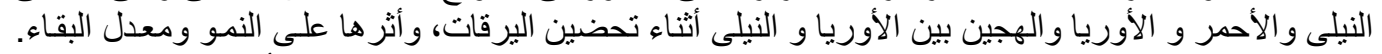

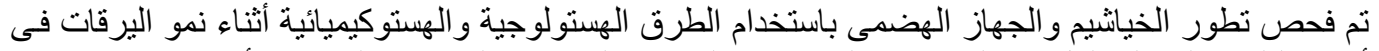

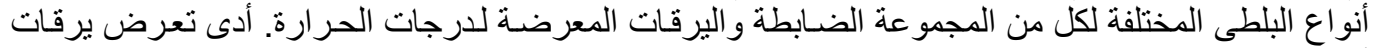

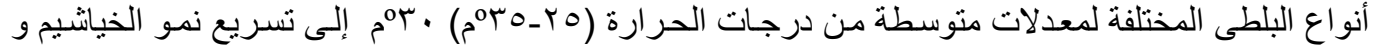

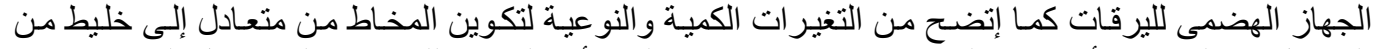

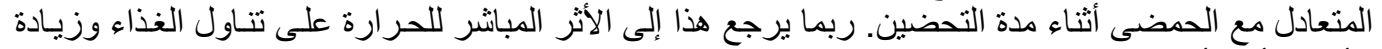

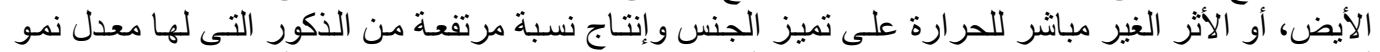

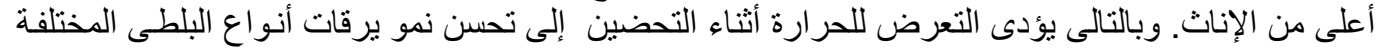

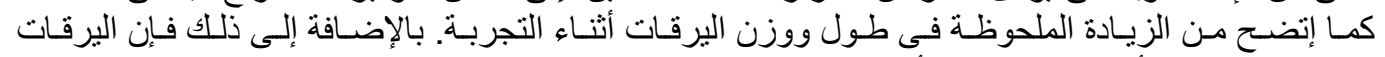

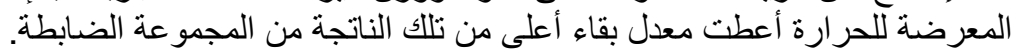

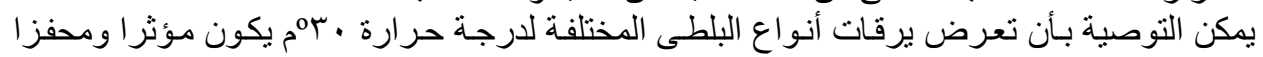

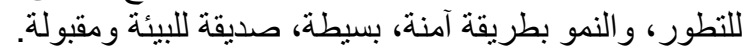

